\title{
Preparation, Study of Performance and Emission Characteristics of Diesel Engine Fuelled with Waste Cooking Oil Biodiesel
}

\author{
Chiranjivi Bharat Pinapati ${ }^{1}$, Likhith Nalluri ${ }^{2}$, Praveen Kumar Alagiri ${ }^{3}$ \\ 1,2,34th Year, Department of Mechanical Engineering 2014, Amrita Vishwa Vidyapeetham, Bangalore, Karnataka, India
}

\begin{abstract}
Biodiesel production and application are gaining popularity in recent times due to diminishing petroleum reserves and detrimental environmental impacts. There are many available edible oils (Palm oil, coconut oil etc.) and non-edible oils (Jatropha oil, Cotton seed oil etc.) but the use of alternative feedstock as waste cooking oils for biodiesel production is cheaper than vegetable oils. Waste cooking oil has high viscosity, so it cannot be used directly on Diesel engines. In this study Waste cooking oil is transesterified using Potassium hydroxide and Sodium hydroxide as catalysts. Experimental tests have been carried out to evaluate the performance and emission characteristics of a single cylinder Diesel engine using different biodiesel blends and standard diesel. A minor decrease in thermal efficiency and a considerable improvement in reduction of smoke, carbon monoxide and unburnt hydrocarbons are observed compared to diesel. The use of transesterified waste cooking oil and its blends as fuel for diesel engines will reduce dependence on fossil fuels and also decrease considerably the environmental pollution.
\end{abstract}

Keywords: Performance characteristics, Diesel engine, Emission characteristics, Waste cooking oil, Biodiesel

\section{Introduction}

The current methods to produce, convert and consume energy derived from fossil fuels throughout the world are not sustainable. With the rise in concern for pollution caused by fossil fuels such as petroleum, coal and natural gas, and the realization that energy supplies are not infinite, alternative fuels and renewable sources of energy are being considered worldwide. Fossil fuel use in transportation is the leading contributor to urban air pollution and to global warming. In recent years, new sulphur and aromatic compound limits give the petroleum producers a new challenge to lower the sulphur and aromatic content of traditional fuel.

For diesel engines several kind of oxygenated fuels are known to have the potential for use as renewable diesel fuel. Those oxygenates include alcohol, ester, ether, carbonate and acetate. Alcohol such as methanol and ethanol have been explored as alternative to conventional diesel fuel, but their low cetane number leads to less than optimal performance in the CI engine [2].

Large number of investigations has been carried out using neat vegetable oils as well as their blends with diesel fuels in varying proportion for different types of diesel engines [1]. Problems like injector choking excessive carbon deposition on piston, cylinder head and engine exhaust manifold, piston ring sticking, fuel filter clogging, and engine oil dilution and polymerization have been reported with the use of vegetable oil particularly during long duration operation of engine.

Recycled vegetable oil, also termed waste cooking oil (WCO) is recovered from businesses and industry that use the oil for cooking. We in this project have recovered the waste vegetable oil from our college mess and canteens. Waste cooking oil is a cheaper alternative when compared to oil obtained from seeds of vegetable plants because the process that is involved in the extraction of oil from seeds utilizes a lot of energy, time and money. Waste cooking oil is preferred as generally after the oil is used for cooking becomes unfit and is thrown away, so utilizing it to prepare biodiesel is very economical and thoughtful. Since one of the major concerns for biodiesel production is the price of feedstock, utilization of waste cooking oil significantly enhances the economic liability of biodiesel production.

Vegetable oils have higher viscosity than commercial diesel fuel, which means they are thicker and flow less easily. For engines designed to burn diesel fuel, the viscosity of vegetable oil must be lowered to allow for proper atomization of the fuel, otherwise incomplete combustion and carbon build up will ultimately damage the engine.

To synthesize and reduce the viscosity of vegetable oils, methods have been developed such as:-

- Dilution (blending)

- Micro-emulsification

- Pyrolysis (thermal cracking)

- Transesterification

Of the several methods available for producing Bio-diesel, Transesterification of vegetable oils is currently the method of choice. The purpose of the process is to lower the viscosity of the oil. Although blending of oil and microemulsifications of vegetable oil lowers the viscosity, engine performance problem still exist. Pyrolysis produces more Biogas than Bio-diesel. Transesterification is basically a sequential reaction and the main factors affecting it are molar ratio of glycerides to alcohol, catalyst. Higher reaction temperatures speed up the reaction and shorten the reaction time [4].

\section{Objective}

To prepare the bio-diesels of waste cooking oil by using base catalysts- sodium hydroxide $(\mathrm{NaOH})$ and potassium hydroxide $(\mathrm{KOH})$ separately and compare their performance and emission characteristics. 


\section{International Journal of Science and Research (IJSR) \\ ISSN (Online): 2319-7064}

Index Copernicus Value (2013): 6.14 | Impact Factor (2015): 6.391

\section{Experimental Details}

\subsection{Preparation of Biodiesel from Waste Cooking Oil}

Waste cooking oil was obtained from our college mess and utilized to prepare biodiesel. For vegetable oil and biodiesel, contaminants must be removed before entering an engine. Injectors, pumps and pistons/seals will be ruined if large particles or the wrong fluids enter them. Engines require lubricating fluids to ensure long operational life.

It is extremely important to filter the waste cooking oil with coarse filters before fine filtering. Fine filters collect practically everything. Which means all that big stuff that would be easy to scrape out of a coarse filter is now embedding itself into the fine filter. Fine filters will be damaged, they will clog fast and it will cost time and money to replace them. Strainers were used for this process. The waste cooking oil was left to settle down for 24 hours and then it was filtered by a normal filtration process using the strainer to remove the large impurities. The filtration was repeated for two times.

The waste cooking oil that is obtained after coarse filtering is taken and then it was heated above $40^{\circ} \mathrm{C}$ so that it would flow easily, which is done mainly to save time. After heating the waste cooking oil it was filtered by using a fine filter and this was repeated for three times to ensure that all the small impurities were removed. The waste cooking oil may contain some amount of water in it. So the waste cooking oil is heated to roughly $100^{\circ} \mathrm{C}$. So once the temperature passes $100 \mathrm{o} \mathrm{c}$, all the water should be boiled out as the boiling point of water is $100^{\circ} \mathrm{C}$. After the pre-treatment of the waste cooking oil was performed, it is made to settle down for 24 hours, after which it is fit to make biodiesel.

The free fatty acid content needs to be found out, so that the amount of catalyst that is neutralized by the weak free fatty acid can be obtained. One gram of potassium hydroxide correctly and dilute completely in $1000 \mathrm{ml}$ of distilled water, this is called titration solution of 0.025 normality. This was done by using a magnetic stirrer so that it dilutes completely into the distilled water. $1 \mathrm{ml}$ of oil is dissolved in $10 \mathrm{ml}$ of Iso-propyl alcohol and 2-3 drops of Phenolphthalein indicator is added.Now this $1 \mathrm{ml}$ oil is titrated with the titrating solution that was prepared initially, to determine how much catalyst is neutralized by the week acid present in the one ml oil.

Titration value is obtained.

- Free Fatty Acid \% from $\mathrm{KOH}$ titration= [Titration Value $] / 1.8$

- Free Fatty Acid \% from $\mathrm{NaOH}$ titration= [Titration Value $] / 1.3$

- $[$ Base + Titration value $] \mathrm{x}$ Litres of oil to react $=$ grams of catalyst

After determining the required amount of catalyst, Transesterification process is done to prepare biodiesel. A known quantity of Waste cooking oil is taken, and then the amount of methanol is calculated (amount of waste cooking oil taken $\mathrm{x}$ 0.20). Now the methanol is mixed with the calculated amount of catalyst using a magnetic stirrer as the catalyst has to be completely dissolved into the methanol. $\mathrm{KOH}$ takes less time to dissolve compared to $\mathrm{NaOH}$. This mixture is called methoxide. Waste cooking oil is heated to $55^{\circ} \mathrm{C}-60^{\circ} \mathrm{C}$ using an induction heater and the oil is allowed to settle, and then the methoxide is mixed. It is then mixed thoroughly using a magnetic stirrer for 2 hours. Now they are allowed to settle down and then transferred it to a separating funnel and left for 24 hours. After the mixture is allowed to settle down for 24 hours, two layers will be obtained. One layer is the biodiesel, generally larger in quantity and the other layer is glycerol, biodiesel is carefully taken out from the separating funnel.These biodiesel is washed with warm water to remove impurities and separated.The optimum proportions are for one litre of used cooking oil, the requirement of methanol and $\mathrm{KOH} / \mathrm{NaOH}$ are $200 \mathrm{ml}$ and $9.8 \mathrm{~g} / 8.3 \mathrm{~g}$ respectively, with this proportion from one litre of Waste cooking oil using $\mathrm{KOH}$ catalyst, $950 \mathrm{ml}$ of biodiesel was produced whereas using $\mathrm{NaOH}$ catalyst, $850 \mathrm{ml}$ of biodiesel is obtained.

\subsection{Engine Testing}

A single cylinder, $3.7 \mathrm{~kW}$ water-cooledC.I. engine coupled with Rope break dynamometer is used for the experimental study and thetechnical specifications are given in Table I.

Table 1: Engine Specifications

\begin{tabular}{|c|c|}
\hline Type & $\begin{array}{c}\text { 4-Stroke, Single Cylinder Diesel } \\
\text { Engine }\end{array}$ \\
\hline Make & Kirloskar AV-1 \\
\hline Rated Power & $3.7 \mathrm{KW}, 1500 \mathrm{rpm}$ \\
\hline Bore and Stroke Length & $85 \times 110 \mathrm{~mm}$ \\
\hline Compression Ratio & $16.5: 1$ \\
\hline Diameter of Brake Drum & $0.36 \mathrm{~mm}$ \\
\hline
\end{tabular}

\section{Results and Discussion}

This paper compares specific fuel consumption, brake thermal efficiency and exhaust emissions of biodiesel prepared using $\mathrm{KOH}$ catalyst, $\mathrm{NaOH}$ catalyst and its blends respectively with those ofdiesel.

\subsection{Performance Characteristics}

The experiments were conducted to evaluate the performance of the diesel engine with Waste Cooking oil bio-diesel blend prepared from $\mathrm{KOH}$ catalyst and $\mathrm{NaOH}$ catalyst of this with diesel at $10 \%, 20 \%, 30 \%$ and $40 \%$.

\subsubsection{Brake Specific Fuel Consumption (BSFC)}


International Journal of Science and Research (IJSR)

ISSN (Online): 2319-7064

Index Copernicus Value (2013): 6.14 | Impact Factor (2015): 6.391

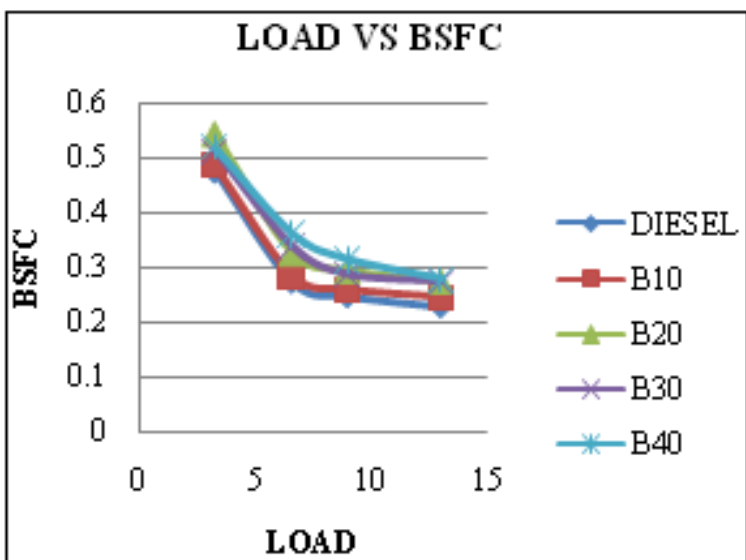

Figure 1: Variation of BSFC with load (KOH catalyst)

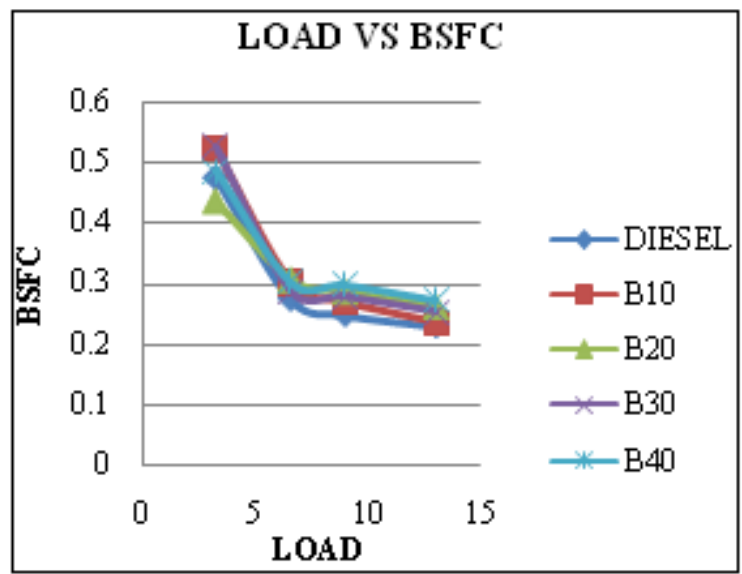

Figure 2: Variation of BSFC with load ( $\mathrm{NaOH}$ catalyst)

The Brake specific fuel consumption for different WCO biodiesel blends (prepared using $\mathrm{KOH}$ catalyst) at different load is reported in Figure 1. The variation of SFC with load for diesel with WCO biodiesel blends (prepared using $\mathrm{NaOH}$ catalyst) is shown in Figure 2.

The Brake specific fuel consumption is defined as the fuel consumed by engine in gm for per $\mathrm{kW}$ per hour. The brake specific fuel consumption $(\mathrm{g} / \mathrm{kWh})$ decreases as the load increases for all type of fuel combination. The reason behind that may be, at high load, the cylinder wall temperature get increased, which reduces the ignition delay.

Thus, shortening of ignition delay improves combustion and reduces fuel consumption. It is observed that brake specific fuel consumption for blends of waste cooking oil biodiesel in different proportions is more when compared with diesel. This is due to the lower calorific values of the blends of waste cooking oil biodiesel when compared with diesel.

\subsubsection{Brake Thermal Efficiency}

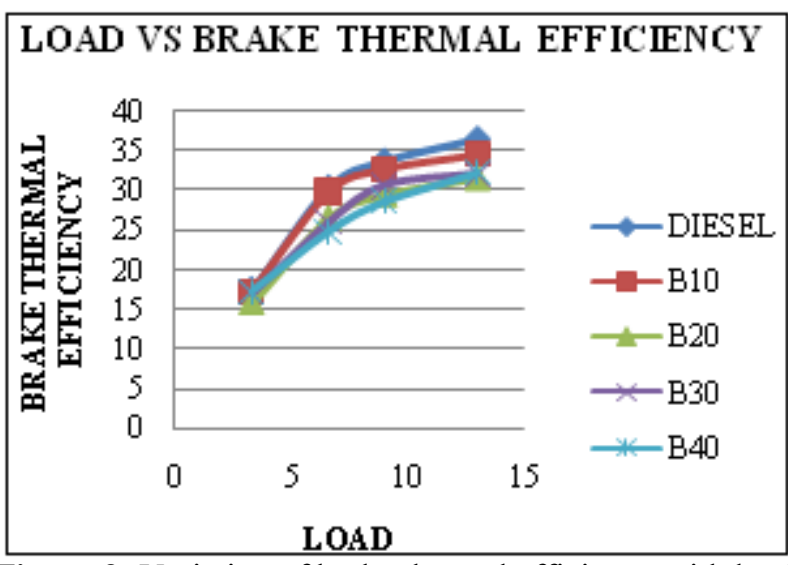

Figure 3: Variation of brake thermal efficiency with load ( $\mathrm{KOH}$ catalyst)

Figure 3 shows the brake thermal efficiency of waste cooking oil biodiesel blends prepared using $\mathrm{KOH}$ catalyst and diesel at different loads. It was found that BTE of Waste cooking oil biodiesel and its blends is slightly lower than that of diesel fuel, the maximum BTE of diesel fuel is $36 \%$ and those of biodiesel blends is B10 at 34\%.

The brake thermal efficiency for Waste cooking oil biodiesel prepared using $\mathrm{NaOH}$ catalyst at different loads is given in Figure 4. The brake thermal efficiency for this biodiesel for all blends range (B10-B40) was found almost comparable to efficiency of diesel fuel. The brake thermal efficiency for B10 (36\%) was only $0.5 \%$ lesser than diesel.

The reason for higher efficiency for B10 may be because of better combustion due to inherent oxygen and higher cetane number. Beyond that efficiency decreases, this may be due to biodiesel's lower heating value, higher density and increased viscosity which leads to poor atomization and fuel vaporization. It is observed that Brake thermal efficiency is increasing with increase in load.

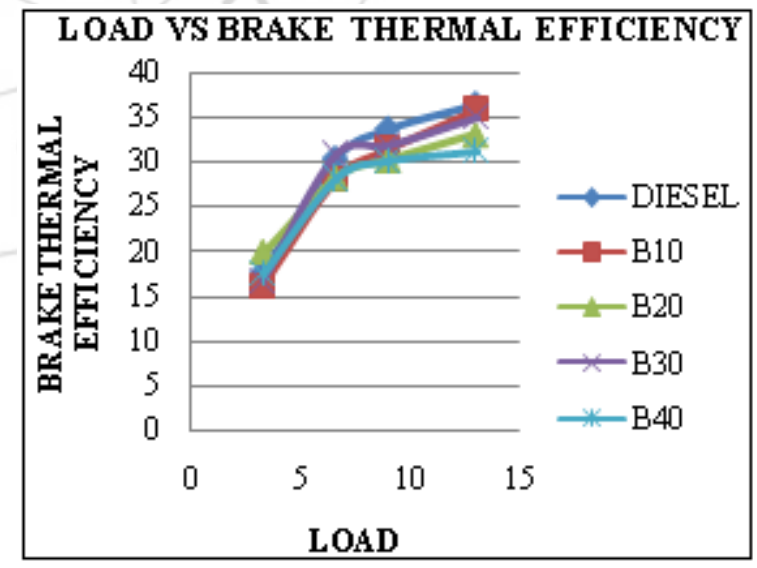

Figure 4: Variation of brake thermal efficiency with load ( $\mathrm{NaOH}$ catalyst)

\subsection{Emission Characteristics}

\subsubsection{Exhaust gas temperature}


International Journal of Science and Research (IJSR)

ISSN (Online): 2319-7064

Index Copernicus Value (2013): 6.14 | Impact Factor (2015): 6.391

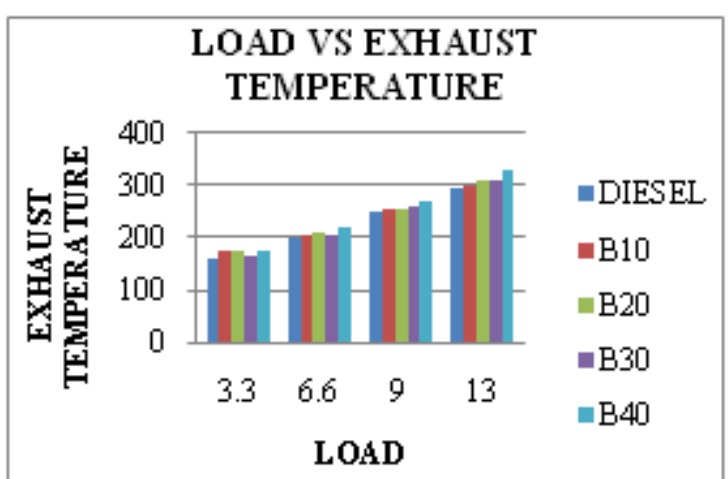

Figure 5: Variation of exhaust gas temperature with load ( $\mathrm{KOH}$ catalyst)

Figure 5 shows the variation of exhaust gas temperature with load for WCO biodiesel blends (prepared using $\mathrm{KOH}$ catalyst) and diesel. The results show that the exhaust gas temperature increases with increase in load for all blends. At all loads, diesel was found to have the lowest temperature and the temperatures for various blends show an upward trend with increasing concentration of WCO biodiesel in the blends. The biodiesel contains oxygen which enables the combustion process and hence the exhaust gas temperatures are higher. Moreover the engine being air cooled runs hotter which resulted in higher exhaust gas temperatures.

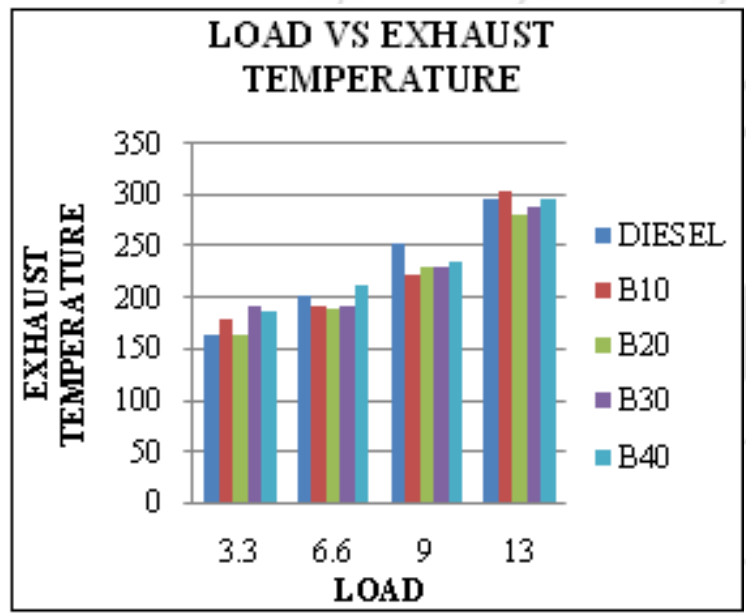

Figure 6: Variation of exhaust gas temperature with load ( $\mathrm{NaOH}$ catalyst)

Figure 6 shows the exhaust gas temperature variations for WCO biodiesel blends (prepared using $\mathrm{NaOH}$ catalyst) with load. It is observed that the exhaust gas temperature increases with load because more fuel is burnt at higher loads to meet the power requirement.

\subsubsection{Carbon Monoxide Emission}

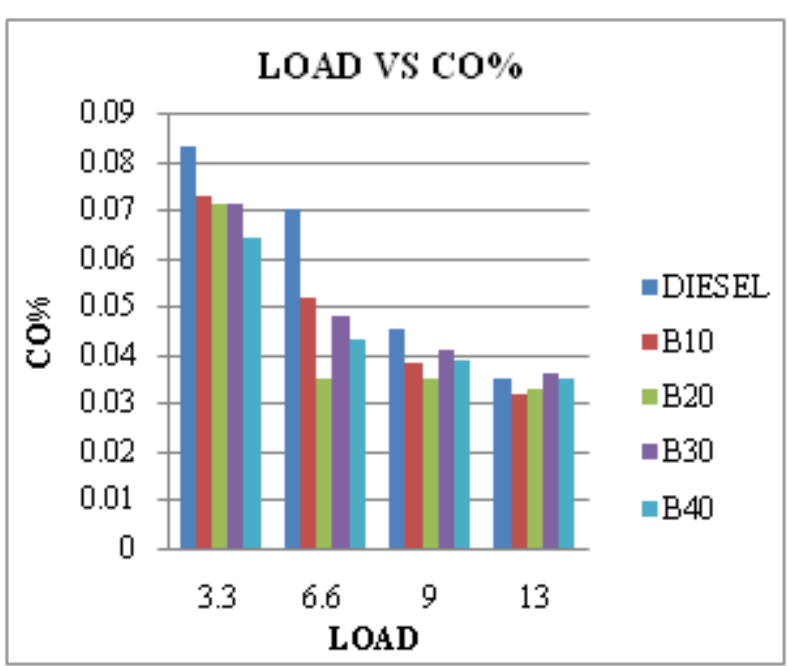

Figure 7: Variation of co \% with load ( $\mathrm{KOH}$ catalyst)

Figure 7 gives the comparison of the carbon monoxide (CO) emission of WCO biodiesel (prepared using $\mathrm{KOH}$ ) and its blends with conventional diesel. Experimental results reveal that $\mathrm{CO}$ concentration of biodiesel and its blends is $12 \%$, $13 \%, 13 \%$ and $22 \%$ lesser for B10, B20, B30 and B40, respectively, when compared to diesel fuels operation.

Figure 8 shows the carbon monoxide $(\mathrm{CO})$ emissions versus load with the use of diesel and WCO biodiesel (prepared using $\mathrm{NaOH}$ ). In comparison with diesel fuel, $\mathrm{CO}$ emissions for biodiesel fuels are lower. On average, $\mathrm{CO}$ emissions of all engine loads for waste cooking oil biodiesel compared to those of diesel fuel decreased by $7 \%$. This can be attributed to molecular oxygen content in biodiesels, which leads to lower $\mathrm{CO}$ emissions. $\mathrm{CO}$ is predominantly formed due to the lackof oxygen. Since WCO biodiesel is an oxygenated fuel, it leads to better combustion of fuel resulting in the decrease in $\mathrm{CO}$ emission.

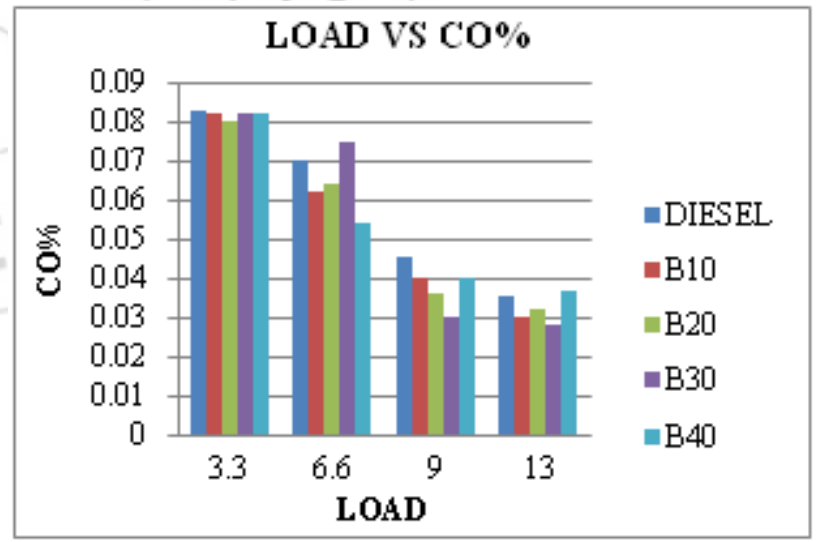

Figure 8: Variation of co \% with load ( $\mathrm{NaOH}$ catalyst)

\subsubsection{Hydrocarbons Emission (HC)}


International Journal of Science and Research (IJSR)

ISSN (Online): 2319-7064

Index Copernicus Value (2013): 6.14 | Impact Factor (2015): 6.391

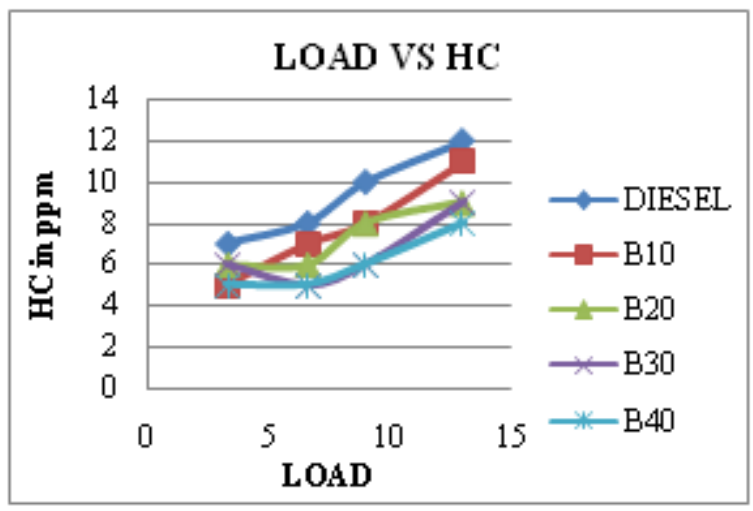

Figure 9: Variation of Hydrocarbon emissions with load ( $\mathrm{KOH}$ catalyst)

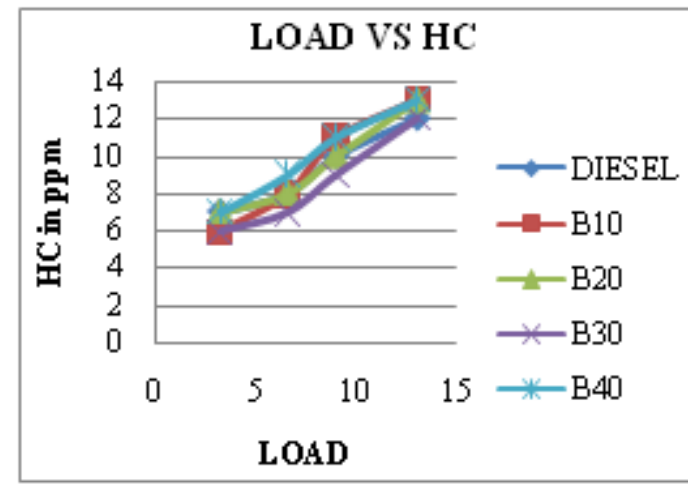

Figure 10: Variation of Hydrocarbon emissions with load ( $\mathrm{NaOH}$ catalyst)

The unburned hydrocarbon emission trends for all WCO biodiesel blends (prepared using $\mathrm{KOH}$ catalyst) and diesel are shown in Figure 9. It is shown that unburned hydrocarbon emissions decrease with increasing WCO biodiesel percentage in the blend. It is also observed that $\mathrm{HC}$ emission increases as the load of the engine was increasing with diesel and blends of WCO biodiesel as the result of increase in fuel consumption at high engine loads.

A $33 \%$ reduction of $\mathrm{HC}$ in the case of $\mathrm{B} 40$ as compared to diesel indicates better combustion of WCO biodiesel. WCO biodiesel involves high oxygen content, which leads to more complete combustion. The unburned $\mathrm{HC}$ emission variation for different WCO biodiesel blends (prepared using $\mathrm{NaOH}$ catalyst) is indicated in Figure 10.

The results demonstrated that $\mathrm{HC}$ emissions increased when the diesel engine was run with B10, B20 and B40 and the increasing rates were about an average in the order of $7 \%$ at full load condition. At higher loads the effects of viscosity have increased these emission levels for the blends.

\subsubsection{Nitrogen Oxides Emission}

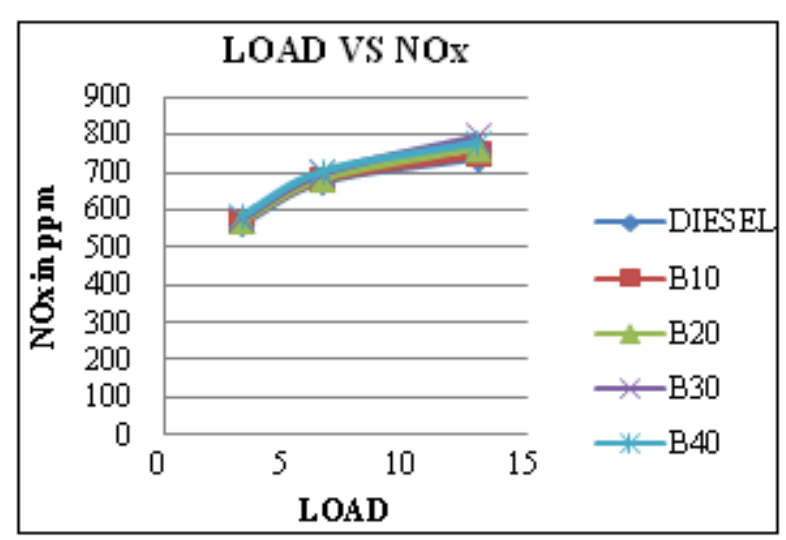

Figure 11: Variation of NOx with load ( $\mathrm{KOH}$ catalyst)

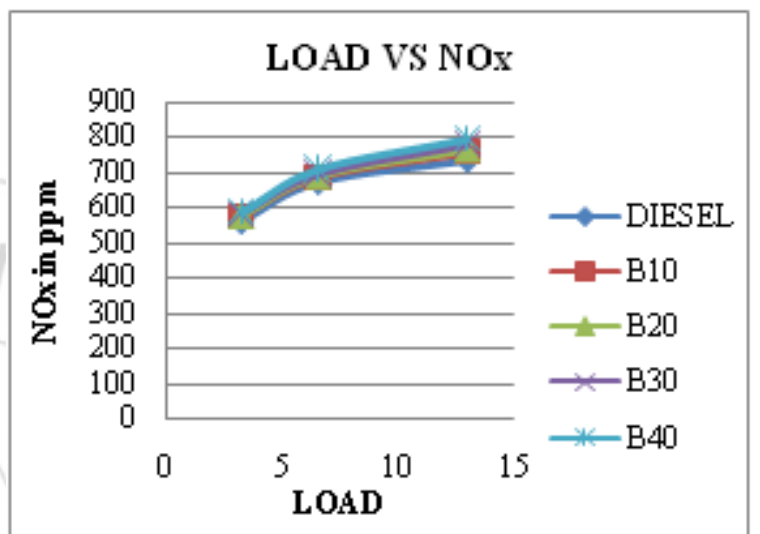

Figure 12: Variation of $\mathrm{NOx}$ with load ( $\mathrm{NaOH}$ catalyst)

The variation of NOx emissions with engine load for the WCO biodiesel (prepared using $\mathrm{KOH}$ catalyst) can be seen in Figure 11. As shown in the figure, it is clear that the NOx emissions varied considerably with the test fuels at all the engine speeds. All the fuel blends produced higher NOx emissions relative to diesel fuel. Among the tested fuels, B30 produced the highest NOx emission at full load condition. NOx emissions with B10, B20, B30 and B40 increased about an average of 2, 4, 8 and $7 \%$ at all the operating conditions when compared with diesel fuel. Increasing NOx emissions is an indicator of higher heat release and it can be explained by the decrease of the cetane number with the addition of oxygenates.

Figure12 shows gradual increase in the emission of nitrogen oxides (NOX) with increase in percentage of WCO biodiesel (prepared using $\mathrm{NAOH}$ catalyst) in the fuel. The formation of NOx in the cylinder is affected by oxygen content, combustion flame temperature and reaction time. NOx formation of all WCO biodiesel blends is slightly higher than that of diesel fuel and NOx content of B40 is $8.01 \%$ higher than conventional diesel fuel under full load condition. It is also observed that as load increases, the NOx formation increases and attains maximum value at maximum load. This is due to higher temperature of combustion and the presence of oxygen with biodiesel cause higher NOx emission.

\section{Conclusions}

The performance, emissions and combustion characteristics of diesel engine fueled with waste cooking oil biodiesel and its blends have been analyzed, and compared to the baseline 


\section{International Journal of Science and Research (IJSR) \\ ISSN (Online): 2319-7064}

Index Copernicus Value (2013): 6.14 | Impact Factor (2015): 6.391

diesel fuel. The results of present work are summarized as follows:-

1) The specific fuel consumption increases with increase in percentage of waste cooking oil in the blend due to the lower calorific value of waste cooking oil

2) The brake thermal efficiency decreases with increase in percentage of waste cooking oil in the fuel

3) Increase in oxygen content in the waste cooking oil-diesel blends as compared to diesel results in better combustion and increase in the combustion chamber temperature. This leads to increase in NOx. Waste cooking oil recorded an average of $7 \%$ increase values of $\mathrm{NOx}$ compared to diesel at different load

4) Emissions of $\mathrm{CO}$ and unburned $\mathrm{HC}$ decrease with increase in percentage of waste cooking oil in the blend

5) It is also observed that there is a significant reduction in smoke opacity especially at higher loads with B20 waste cooking oil

6) The yield obtained was $95 \%$ using $\mathrm{KOH}$ catalyst whereas $85 \%$ using $\mathrm{NaOH}$ catalyst

7) The used cooking oil as feedstock for transesterification reduces the production cost of biodiesel

8) When comparing the performance characteristics there was not much change between $\mathrm{KOH}$ and $\mathrm{NaOH}$ but emission characteristics of $\mathrm{KOH}$ is slightly better than $\mathrm{NaOH}$

\section{References}

[1] Krishna Pandey. C, Pandey K. P., Gosh B.B. and Ramanujam S. "Critical review on Vegetable oils as substitute fuel for diesel engine" I.C Engines and combustion. P.K. Bose (Editor) Narosa publishing house, New Delhi

[2] Irshad Ahmed, "Oxygenated diesel; Emission and performance characteristics of ethanol-diesel blend in C.I engine".

[3] Mustafa Canakaci and John H. Van Gerpen, "Comparision of engine performance and emissions for petroleum diesel fuel, soybean oil biodiesel".

[4] Ziejewski M, Goettler H, Pratt GL. Paper No. 860301, International Congress and Exposition, Detroit, MI, 2428 February, 1986.

[5] Rosca Radu, Carlescu Petru, Rakosi Edward, Manolache Gheorghe "Fuelling an diesel engine with waste oil biodiesel" effects over injection, combustion and engine characteristics.

[6] Biodiesel production: a review by Fangrui Maa, Milford A. Hannab.

[7] A. Babu and G. Devaradjane, " Vegetable Oils And Their Derivatives As Fuels For CI Engines: An Overview," SAE Technical Paper 2003-01-0767, 2003 